
pain disorders. Journal of Education, Health and Sport. 2020;10(9):915-926. eISSN 2391-8306. DOI http://dx.doi.org/10.12775/JEHS.2020.10.09.112

https://apcz.umk.pl/czasopisma/index.php/JEHS/article/view/JEHS.2020.10.09.112

https://zenodo.org/record/4062203

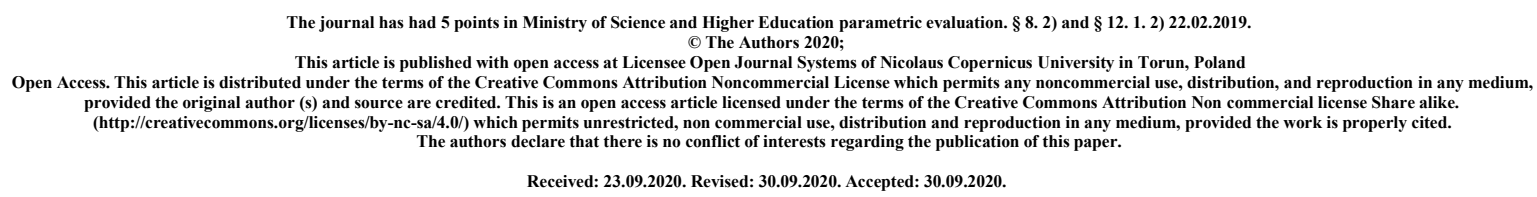

\title{
Effectiveness of craniosacral therapy in musculoskeletal pain disorders
}

\section{Kacper Pajor ${ }^{1}$, Justyna Szpyt ${ }^{1}$, Agnieszka Turoń-Skrzypińska ${ }^{2}$, Iwona Rotter ${ }^{2}$}

1. Students' Science Club of Department of Medical Rehabilitation and Clinical Physiotherapy, Pomeranian Medical University in Szczecin, ul. Żołnierska 54, 70-204 Szczecin, Poland

2. Department of Medical Rehabilitation and Clinical Physiotherapy, Pomeranian Medical University in Szczecin, ul. Żołnierska 54, 70-204 Szczecin, Poland

\section{Address for correspondence}

Kacper Pajor, e-mail: kontakt@kacperpajor.pl

\section{Abstract \\ Introduction}

Craniosacral therapy is becoming more and more popular among therapists around the world. Its activity is based on primary respiratory mechanism (PSM), a natural craniosacral rhythm consisting of two phases: flexion and extension. During therapy, the therapist, using appropriate manual techniques performed with minimal force, restores the physiological craniosacral rhythm, restores the mobility of the cranial sutures and affects the mobility of the central nervous system. Due to not fully understood mechanisms of action and controversial foundations, the effectiveness of craniosacral therapy is often questioned.

\section{Purpose}

The purpose of this research review is to determine the effectiveness of craniosacral therapy on musculoskeletal pain disorders.

\section{Material and methods}

The PubMed database was searched using "Craniosacral therapy" for clinical trials and randomized clinical trials. Studies with other forms of therapy or placebo, conducted on newborns and older than 15 years and were excluded. These exclusions narrowed the search results to 5 works.

\section{Results}

Each study reported statistically significant improvement in at least one type of perceived pain in intervention group. In all studies, in at least two of the assessed tests (assessing pain and functionality), the difference between the result before the therapy and the result achieved 
after the therapy improved more for the group undergoing craniosacral therapy. Moreover, a review of studies showed insufficient level of research explaining the physiological foundations of craniosacral therapy.

\section{Conclusions}

1. Craniosacral therapy can effectively reduce pain of musculoskeletal origin and increase the functionality of patients. 2. The mechanisms responsible for the effectiveness of craniosacral therapy and its theoretical foundations require further research.

Keywords: craniosacral therapy, manual therapies, osteopathic manipulative treatment

\section{Introduction}

While developing, physiotherapy borrows its individual elements from other fields, which leads to the implementation of new therapeutic techniques. One example of such a course of events is the borrowing of craniosacral therapy, which was developed in 1939 by William Garner Sutherland as one of the methods of osteopathy. Starting with single techniques, therapists were more and more willing to apply elements of craniosacral work in their therapies, which led to the establishment of the Upledger Institute International, providing full training in craniosacral therapy. Currently, craniosacral therapy courses are very popular and are conducted by various organizations around the world [1]. Along with the spread of this form of therapy, more and more questions about its effectiveness arise.

Craniosacral therapy is based on the primary respiratory mechanism (PSM), a natural craniosacral rhythm during which the craniosacral system regularly changes its volume. We distinguish between two phases: flexion (also called "inhalation"), i.e. when the intrathecal pressure increases and the craniosacral system is stretched, and extension ("exhalation"), when there is a resorption of the cerebrospinal fluid. This rhythm occurs in humans with an amplitude from 6 to 10 times per minute, and both phases should last a similar amount of time [2]. During therapy, it is assessed by palpation, and experienced therapists declare the ability to sense it anywhere in the human body, what is is being called into question [3]. 
Cranio-sacral therapy is based on delicate manipulations - the pressure with which the therapist works should correspond to 5 grams. Its aim is to subtly influence the craniosacral rhythm (restore the physiological frequency and duration of flexion and extension), restore the mobility of the cranial sutures and improve the mobility of the central nervous system. As part of craniosacral therapy, relaxation of fascial restrictions is also performed [2]. The full mechanism of craniosacral therapy is not yet fully understood, although the current scientific knowledge indicates that the effectiveness of this type of techniques may be due to the stimulation of the parasympathetic nervous system in response to the therapy [4].

Cranio-sacral therapy has many aspects that raise doubts in the world of physiotherapy. Its effectiveness depends largely on the palpation and manual skills of the therapist, so the repeatability of techniques between physiotherapists differs significantly. The stimulus introduced during the therapeutic session is very small, so its ability to introduce real changes in the body is questioned. Moreover, the work on the skull sutures is also criticized, pointing to their extremely low mobility [3].

Despite numerous voices of criticism, craniosacral therapy is gaining more and more popularity, being taught both as an independent method even in several-year courses, and being present as an element of other trainings, e.g. in osteopathic manipulative treatment (OMT). It is recommended mainly to treat musculoskeletal pain, but the range of indications for its use is much wider. Craniosacral therapy is recommended e.g. in the treatment of headaches, developmental disorders, hyperactivity, dyslexia, depression, bruxism or even cerebral palsy [5].

Research on the degree of effectiveness of craniosacral therapy is often problematic. Repeatability of manual techniques is never $100 \%$, so each subsequent intervention will be slightly different, even when conducted by the same therapist. The changes introduced in the human body through craniosacral techniques are very small, which makes their determination 
and measurement extremely difficult or impossible. Moreover, we should also not forget about the high probability of the placebo effect, which is characteristic of all manual techniques used in physiotherapy $[3,6]$. Due to the large number of obstacles to reliable research, craniosacral therapy is still relatively poorly understood despite its long tradition.

\section{Aim of the study}

In order to determine the usefulness of craniosacral therapy in the work of a physiotherapist, we decided to conduct a research review aimed at determining the effectiveness of this form of therapy against musculoskeletal pain disorders.

\section{Material and methods}




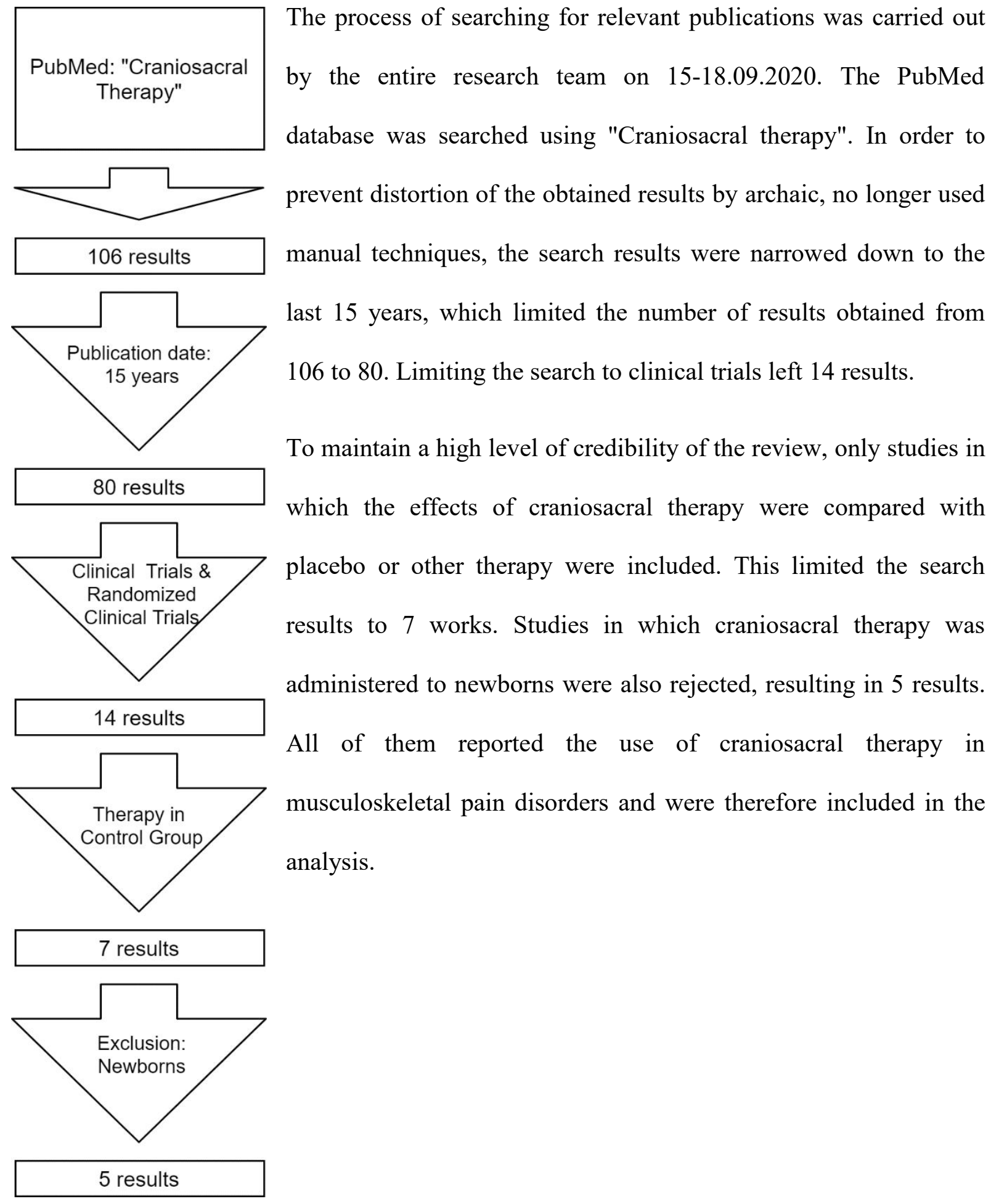

Table 1. Flowchart 


\section{Results}

\begin{tabular}{|c|c|c|c|c|c|c|c|c|}
\hline Author & Year & $\mathrm{N}, \mathrm{Ni}, \mathrm{Nc}$ & $\begin{array}{c}\mathrm{Ai}, \mathrm{Ac} \\
{[\mathrm{yr}]}\end{array}$ & Tests & Disease & $\begin{array}{l}\text { CS Therapy } \\
\text { characteristics }\end{array}$ & $\begin{array}{l}\text { Control Group } \\
\text { characteristic }\end{array}$ & Significant changes $(\mathrm{IGvsCG})(\mathrm{p}<0,005)$ \\
\hline $\begin{array}{l}\text { Adelaida } \\
\text { et al. [7] }\end{array}$ & 2016 & $64,32,32$ & $\begin{array}{c}50 \pm 12 \\
53 \pm 9\end{array}$ & $\begin{array}{l}\text { RMQ, ODI, Pain } \\
\text { (NPRS 0-10), } \\
\text { TSK, Electro } \\
\text { interstitial } \\
\text { scanner, } \\
\text { Interstitial liquid } \\
\text { biochemical } \\
\text { estimation, } \\
\text { McQuade test, } \\
\text { Finger-to-floor } \\
\text { distance } \\
\end{array}$ & $\begin{array}{l}\text { Chronic } \\
\text { nonspecific } \\
\text { LBP }\end{array}$ & $\begin{array}{l}\text { 10x1/week, } 50 \\
\min \end{array}$ & $\begin{array}{l}\text { Massage, } \\
\text { 10x1/week, } 30 \\
\text { min }\end{array}$ & $\begin{array}{l}\text { Pain intensity }-2.0 \text { vs }+0.02 \\
\text { Systolic blood pressure }-10.87 \text { vs }+8.25\end{array}$ \\
\hline $\begin{array}{l}\text { Elden et } \\
\text { al. [8] }\end{array}$ & 2013 & $123,63,60$ & $\begin{array}{l}30.6 \pm 3.9 \\
31.3 \pm 4.3\end{array}$ & $\begin{array}{l}\text { Pain (VAS 0- } \\
\text { 100), Frequency } \\
\text { of sick leave, } \\
\text { ODI, DRI, EQL, } \\
\text { Discomforton } \\
\text { PGP (VAS 0- } \\
\text { 100), Recovery } \\
\text { or severity of } \\
\text { PGP } \\
\text { (provocation } \\
\text { tests - markings } \\
\text { on the pain } \\
\text { drawing and } \\
\text { VAS 0-100) }\end{array}$ & $\begin{array}{l}\text { Pelvic Girdle } \\
\quad \text { Pain }\end{array}$ & $\begin{array}{c}\text { Education }+ \\
\text { exercises }+ \\
\text { elastic pelvic belt } \\
+ \text { craniosacral } \\
\text { therapy }\end{array}$ & $\begin{array}{l}\text { Education }+ \\
\text { exercises }+ \\
\text { elastic pelvic } \\
\text { belt }\end{array}$ & $\begin{array}{l}\text { Pain related to motion intensity in the morning }-0.5 \mathrm{vs}+7 \\
\text { ODI Score } 4 \mathrm{vs} 12 \\
\text { Modified trendelenburg test } 22 \mathrm{vs} 6 \\
\text { Symptom-free participiants } 2 \mathrm{vs} 11\end{array}$ \\
\hline $\begin{array}{l}\text { Adelaida } \\
\text { et al. [9] }\end{array}$ & 2011 & $92,46,46$ & $\begin{array}{l}53.85 \pm 10 \\
12 \\
51.34 \pm 13 \\
07\end{array}$ & $\begin{array}{c}\text { Body } \\
\text { composition } \\
\text { BIA, Tender } \\
\text { point pressure } \\
\text { algometry, ECG, } \\
\text { CGIs, CGI-I, }\end{array}$ & Fibromyalgia & $\begin{array}{l}\text { 20x2/week, } 60 \\
\min \end{array}$ & $\begin{array}{l}\text { Placebo, } \\
\text { 20x2/week, } 60 \\
\text { min }\end{array}$ & $\begin{array}{l}\text { After } 20 \text { weeks: } \\
\text { CGI-S }-0,57 \text { vs }+0,08 \\
13 \text { tender points significantly improved in IG group vs } 0 \text { in } C G \\
\text { CGI-I } 5.02 \text { vs } 6.20 \\
\text { After } 2 \text { months: } \\
\text { CGI-I } 5.99 \text { vs } 6.30 \\
9 \text { tender points improved in IG group vs } 0 \text { in CG }\end{array}$ \\
\hline
\end{tabular}




\begin{tabular}{|c|c|c|c|c|c|c|c|c|}
\hline & & & & & & & & $\begin{array}{l}\text { After } 1 \text { year: } \\
\text { CGI-I } 6.14(0.80) 6.43 \\
4 \text { tender points improved vs } 0 \text { in CG }\end{array}$ \\
\hline $\begin{array}{l}\text { Heidemari } \\
\text { e et al. } \\
\text { [10] }\end{array}$ & 2016 & $54,27,27$ & $\begin{array}{l}44.6 \pm 10.0 \\
45.0 \pm 10.5\end{array}$ & $\begin{array}{c}\text { Pain and pain on } \\
\text { movement (VAS } \\
0-100) \text {, pressure } \\
\text { pain sensitivity, } \\
\text { NDI, SF-12, } \\
\text { FEW, HADS, } \\
\text { PSQ, ERDA, } \\
\text { SBC, PGI-I, }\end{array}$ & $\begin{array}{c}\text { Chronic Neck } \\
\text { Pain }\end{array}$ & $\begin{array}{c}8 \times 1 / \text { week, } 45 \\
\min \end{array}$ & $\begin{array}{l}\text { Placebo, light } \\
\text { touch, } \\
8 \times 1 / \text { week, } 45 \\
\text { min }\end{array}$ & $\begin{array}{l}\text { After } 8 \text { weeks } \\
\text { Pain intensity }-32.6 \text { to }-9.4 \text {, } \\
\text { Pain of movement }-29.2 \text { to }-8.0 \\
\text { Point of max pain } 2.8 \text { to } 97.7 \text {, } \\
\text { Trapezius pain } 1.2 \text { to } 62.4 \\
\text { Functional disability }-14.4 \text { to }-2.1 \\
\text { Physical quality of life } 1.3 \text { to } 10.4 \\
\text { Body awareness } 0.1 \text { to } 0.5 \\
\text { Global improvement } 1.5 \text { to } 0.5 \\
\text { After } 20 \text { weeks } \\
\text { Pain intensity }-27.5 \text { to }-6.1 \\
\text { Pain of movement }-20.9 \text { to }-1.9 \\
\text { Functional disability }-11.1 \text { to }-2.0 \\
\text { Physical quality of life } 2.8 \text { to } 9.1 \\
\text { Anxiety }-3.8 \text { to }-0.3 \\
\text { Global improvement }-1.3 \text { to }-0.1\end{array}$ \\
\hline $\begin{array}{l}\text { Mammad } \\
\text { et al. [11] }\end{array}$ & 2007 & $23,11,12$ & $\begin{array}{c}51.7 \pm 9.4 \\
52.4 \pm 7.17\end{array}$ & $\begin{array}{l}\text { Grip strength } \\
\text { (dynanometer), } \\
\text { Adopted PSFS, } \\
\text { Pain (NRS) }\end{array}$ & $\begin{array}{c}\text { Lateral } \\
\text { Epicondylitis }\end{array}$ & $\begin{array}{l}6 \text { sessions, } 2-3 \\
\text { weeks, } 20-30 \\
\text { mins }\end{array}$ & $\begin{array}{l}\text { Placebo, light } \\
\text { touch, } 6 \\
\text { sessions, } 2-3 \\
\text { weeks, } 20-30 \\
\text { mins }\end{array}$ & $\begin{array}{l}\text { Grip strength }+12,3 \text { to }-1,9 \\
\text { Pain intensity }-3,1 \text { to }-0,5 \\
\text { Functional level } 14,5 \text { to } 4,7 \\
\text { Pain limited activity }+3,3 \text { to }-0,1\end{array}$ \\
\hline
\end{tabular}

Table 2. Results 


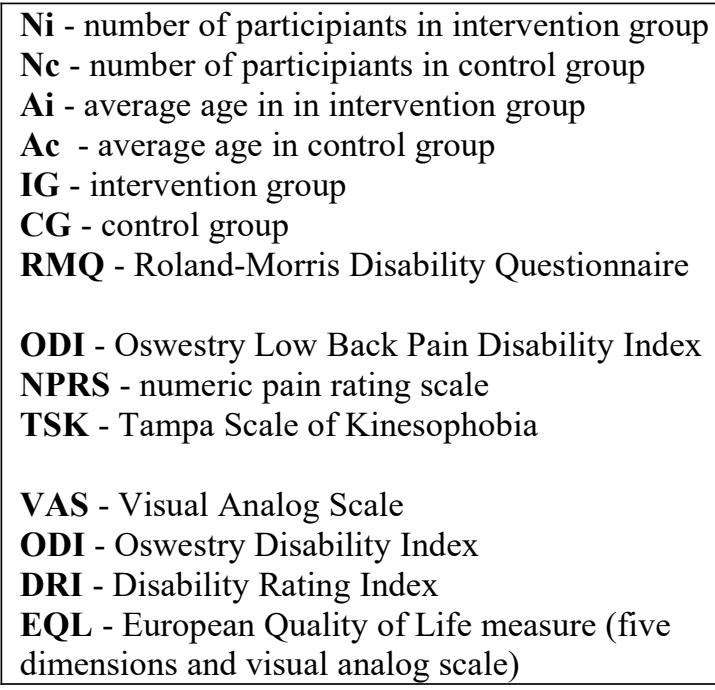

Table 3. Abbreviation table

In all analyzed studies, statistically significant improvement was demonstrated in some of the tests performed in intervention group. Also in all studies, in at least two of the assessed tests, the difference between the result before the therapy and the result achieved after the therapy improved more for the group undergoing craniosacral therapy. Each study reported statistically significant improvement in at least one type of perceived pain in intervention group. Four out of five studies also reported a significant improvement in functionality among people undergoing craniosacral therapy.

\section{Discussion}

All analyzed studies showed statistically significant improvement as a result of craniosacral therapy, greater than in the control groups, treated with massage or placebo. This result indicates that, despite the incomplete explanation of the mechanism of physiological changes introduced in the body during this type of therapy, it can be an effective tool for reducing pain of musculoskeletal origin. Selecting for review only studies in which the control group was subjected to a different type of therapy additionally increases the significance of these results. A large part of the results achieved during manual therapy is attributed to the placebo effect, therefore the effectiveness of therapies performed with the hands of a physiotherapist is often 
questioned [12]. There are even studies indicating the need to increase the conscious participation of placebo in the patient's therapy process in order to improve the effectiveness of treatment [13]. In light of these indications and results summarized in the above review, craniosacral therapy becomes an really interesting issue from the point of view of scientific research. Its effectiveness is significantly greater than that of placebo therapy, despite the lack of a comprehensive explanation of the principles of its operation. In the light of the available literature, insufficient research into craniosacral therapy seems to be the main problem regarding this form of manual treatment.

The low availability of studies investigating craniosacral therapy is already visible at the stage of the material collected in this review. Despite the growing popularity of this form of therapy and thousands of therapists working with it [1], in the last 15 years there have been only 5 studies comparing it with other therapies or placebo in the treatment of musculoskeletal pain in adults. The shortage of scientific studies also concerns the basic assumptions of craniosacral therapy. The cranio-sacral rhythm patterns, the movement of the skull bones around the sutures and its manual modification, or the correlations between restrictions in the craniosacral system and health are rarely studied, and the quality of these studies is often unsatisfactory [14].

Undoubtedly, an obstacle in the study of craniosacral therapy is a large number of potential problems encountered at the stage of standardization of works, mentioned in the introduction to the review, resulting from the large component of subjective feelings of the therapist in therapy. However, it should be borne in mind that the same problems are encountered in teaching and practicing craniosacral therapy. The ability to palpate the craniosacral rhythm is questioned in the literature. The differences noted between the feelings of experienced therapists examining the same person at the same time raise doubts as to the possibility of effective, reliable teaching and practicing this form of diagnostics $[15,16]$. Doubts are also 
raised by the ability of young therapists to effectively repeat the techniques of craniosacral therapy. As a rule, it requires advanced palpation skills and work with minimal sensations, while studies indicate that palpation of physiotherapists may fail at the level of finding specific spinous processes that are easily accessible and incomparably better perceptible than cranial bone movements [17].

The assumptions underlying the techniques used in craniosacral therapy are also criticized. Research indicates that the pressure applied during craniosacral therapy cannot introduce changes such as improved mobility of the skull sutures. Studies on animal models show that changing the position of the skull bones in relation to each other requires a force many times higher than that used during craniosacral therapy [18].

Despite all these doubts, craniosacral therapy in studies shows the ability to reduce pains from the musculoskeletal system and has a positive effect on the degree of functionality of patients. These results stand in opposition to the criticism of craniosacral therapy. The relatively low availability of high-quality scientific studies certainly does not help in an objective assessment of this form of therapy.

\section{Summary}

Craniosacral therapy is more effective in the treatment of musculoskeletal pain than massage therapy or placebo. However, in the current state of knowledge, we cannot determine the mechanism responsible for reducing pain and improving the functionality of the body in response to this form of therapy. Both the assumptions and methods used in craniosacral therapy do not have an exhaustive explanation in scientific studies. Further work on craniosacral therapy is highly needed to understand why this therapy is effective. Understanding its mechanisms may also positively affect the results achieved with its use.

\section{Conclusions}


1. Craniosacral therapy can effectively reduce pain of musculoskeletal origin and increase the functionality of patients.

2. The mechanisms responsible for the effectiveness of craniosacral therapy and its theoretical foundations require further research.

\section{Bibliografia}

1. Chaitow L. Cranial Manipulation Theory and Practice: Osseous and Soft Tissue Approaches. Toronto: Churchill Livingstone; 1999.

2. Miszewski W, Miszewska A. Modern methods of physiotherapy - craniosacral therapy. Med Rodz. 2014;3:141-146.

3. Sommerfeld P, Kaider A, Klein P. Inter-and intraexaminer reliability in palpation of the "primary respiratory mechanism" within the "cranial concept". Man Ther. 2004;9(1):22-29.

4. Haller H, Lauche R, Sundberg T, Dobos G, Cramer H. Craniosacral therapy for chronic pain: a systematic review and meta-analysis of randomized controlled trials. BMC Musculoskelet. Disord. 2020;21(1):1-14.

5. Upledger J. Your inner physician and you: CranioSacral therapy and SomatoEmotional release. North Atlantic Books; 1997.

6. Bialosky J, Bishop M, George S, Robinson M. Placebo response to manual therapy: something out of nothing?. J Man Manip Ther. 2011;19(1):11-19.

7. Castro-Sánchez A, Lara-Palomo I, Matarán-Penarrocha G, Saavedra-Hernández M, PérezMármol J, Aguilar-Ferrándiz M. Benefits of Craniosacral therapy in patients with chronic low Back pain: a randomized controlled trial. J Altern Complement Med. 2016;22(8):650-657.

8. Elden H, Östgaard H, Glantz A, Marciniak P, Linnér A, Olsén M. Effects of craniosacral therapy as adjunct to standard treatment for pelvic girdle pain in pregnant women: a multicenter, single blind, randomized controlled trial. Acta Obstet Gynecol Scand. 2013;92(7):775-782.

9. Castro-Sánchez A, Matarán-Peñarrocha G, Sánchez-Labraca N, Quesada-Rubio J, GraneroMolina J, Moreno-Lorenzo C. A randomized controlled trial investigating the effects of craniosacral therapy on pain and heart rate variability in fibromyalgia patients. Clin Rehabil. 2011;25(1):25-35.

10. Haller H, Lauche R, Cramer H, Rampp T, Saha F, Ostermann T, Dobos G. Craniosacral therapy for the treatment of chronic neck pain: a randomized sham-controlled trial. Clin $\mathrm{J}$ Pain. 2016;32(5):441.

11. Nourbakhsh M, Fearon F. The effect of oscillating-energy manual therapy on lateral epicondylitis: a randomized, placebo-control, double-blinded study. J Hand Ther. 2008;21(1):4-14.

12. Bialosky J, Bishop M, Penza C. Placebo mechanisms of manual therapy: a sheep in wolf's clothing?. J Orthop Sports Phys Ther. 2017;47(5):301-304.

13. Bialosky J, Bishop M, George S, Robinson M. Placebo response to manual therapy: something out of nothing?. J Man Manip Ther. 2011;19(1):11-19.

14. Green C, Martin C, Bassett K, Kazanjian A. A systematic review of craniosacral therapy: biological plausibility, assessment reliability and clinical effectiveness. Complement Ther Med. 1999;7(4):201-207. 
15. Rogers J, Witt P, Gross M, Hacke J, Genova P. Simultaneous palpation of the craniosacral rate at the head and feet: intrarater and interrater reliability and rate comparisons. Phys Ther. 1998;78(11):1175-1185.

16. Sommerfeld P, Kaider A, Klein P. Inter-and intraexaminer reliability in palpation of the "primary respiratory mechanism" within the "cranial concept". Man Ther. 2004;9(1):22-29.

17. Billis E, Foster N, Wright C. Reproducibility and repeatability: errors of three groups of physiotherapists in locating spinal levels by palpation. Man Ther. 2003;8(4):223-232.

18. Flynn T, Cleland J, Schaible P. Craniosacral therapy and professional responsibility. J Orthop Sports Phys Ther. 2006;36(11):834-836. 